\title{
Needle and syringe sharing among Iranian drug injectors
} Hassan Rafiey*1, Hooman Narenjiha1,2, Peymaneh Shirinbayan1, Roya Noori ${ }^{1}$, Morteza Javadipour ${ }^{3}$, Mohsen Roshanpajouh ${ }^{3}$, Mercedeh Samiei ${ }^{1}$ and Shervin Assari ${ }^{3}$

\author{
Address: ${ }^{1}$ Iranian Research Center for Substance Abuse and Dependence (IRCSAD), University of Social Welfare and Rehabilitation Science, \\ Tehran, Iran, ${ }^{2}$ Drug Control Head Quarters (DCHQ), Tehran, Iran and ${ }^{3}$ Medicine and Health Promotion Institute, Tehran, Iran \\ Email: Hassan Rafiey* - rafieyah@yahoo.com; Hooman Narenjiha - narenjihah@gmail.com; \\ Peymaneh Shirinbayan - peymaneh_s@yahoo.com; Roya Noori - roya_noori2020@yahoo.com; Morteza Javadipour - drmjava@yahoo.com; \\ Mohsen Roshanpajouh - Mohsen_rp@yahoo.com; Mercedeh Samiei - mercesam@yahoo.com; Shervin Assari - assarish@yahoo.com \\ * Corresponding author
}

Published: 30 July 2009

Harm Reduction Journal 2009, 6:21 doi:|0.1|86/1477-75/7-6-21
Received: 7 April 2009

Accepted: 30 July 2009

This article is available from: http://www.harmreductionjournal.com/content/6/1/21

(C) 2009 Rafiey et al; licensee BioMed Central Ltd.

This is an Open Access article distributed under the terms of the Creative Commons Attribution License (http://creativecommons.org/licenses/by/2.0), which permits unrestricted use, distribution, and reproduction in any medium, provided the original work is properly cited.

\begin{abstract}
Objective: The role of needle and syringe sharing behavior of injection drug users (IDUs) in spreading of blood-borne infections - specially HIVIAIDS - is well known. However, very little is known in this regard from Iran. The aim of our study was to determine the prevalence and associates of needle and syringe sharing among Iranian IDUs.
\end{abstract}

Methods: In a secondary analysis of a sample of drug dependents who were sampled from medical centers, prisons and streets of the capitals of 29 provinces in the Iran in 2007, 209I male IDUs entered. Socio-demographic data, drug use data and high risk behaviors entered to a logistic regression to determine independent predictors of lifetime needle and syringe sharing.

Results: 749(35.8\%) reported lifetime experience of needle and syringe sharing. The likelihood of lifetime needle and syringe sharing was increased by female gender, being jobless, having illegal income, drug use by family members, pleasure/enjoyment as causes of first injection, first injection in roofless and roofed public places, usual injection at groin, usual injection at scrotum, lifetime experience of nonfatal overdose, and history of arrest in past year and was decreased by being alone at most injections.

Conclusion: However this data has been extracted from cross-sectional design and we can not conclude causation, some of the introduced variables with association with needle and syringe sharing may be used in HIV prevention programs which target reducing syringe sharing among IDUs.

\section{Introduction}

Human Immunodeficiency Virus (HIV)/Acquired Immunodeficiency disorder syndrome (AIDS) has shown a rapid increasing trend [1]. This problem is closely associated to injecting drug users (IDUs) in Iran, accounting for $67 \%$ of HIV positive cases and $85 \%$ of AIDS cases [2].
HIV studies in Iran have underscored the sharing injecting equipments as the main routes of transmission [3]. In one study, lifetime and last time needle and syringe sharing was reported by $50 \%$ and $25 \%$ of IDUs, respectively [4]. In another study, in a drug treatment sample, more than two-thirds of the IDUs had shared syringes [5]. 
Identifying factors associated with needle and syringe sharing among IDUs is particularly important for HIV prevention [6]. While very little is known about associated factors of needle and syringe sharing among Iranian IDUs [7-9], we here aimed to determine the prevalence and associates of needle and syringe sharing among a sample of IDUs in Iran.

\section{Methods \\ Design and setting}

This is a secondary analysis of a cross-sectional survey on 7,743 individuals as a rapid situation assessment (RSA) performed by the Darius institute. Grant was awarded by the Iranian Research Center for Substance Use and Dependence (DARIUS Institute) affiliated to the University of Social Welfare and Rehabilitation Sciences. The study was approved by the ethical review committee of the university and informed consent was obtained from all the participants after they had been verbally reassured that the information would be kept confidential, especially from correctional system. This study was conducted under the financial aid of the Drugs Control Headquarters (DCHQ). Some other manuscripts have been extracted from this database.

\section{Samples and sampling}

The participants were substance dependent persons according to DSM-IV and sampled from treatment centers $(n=1,217)$, prisons $(n=584)$ and streets $(n=5,860)$ of the capitals of 29 provinces in the Islamic Republic of Iran. The samples from treatment centers were selected at random from newcomers. Prisons sampling was also carried out randomly among those who were registered into the prison within previous 30 days. Snowball approach was used to take sample from streets. The number of samples taken from every province was proportional to the whole population of the province. The sampling started in April 2007 and lasted for 5 months. This sampling method is used as the main sampling strategy of drug use in DCHQ studies.

\section{Process}

The interviews were carried out by university graduates (MS, BS) with drug abuse related majors/degrees who were dispatched to the provinces after being trained through workshops in Tehran (the capital of Islamic Republic of Iran). Each interview took 1 to 1 and a half hour. Data were collected using paper-based questionnaire namely Inventory for Drug Dependency-IV, which was the modified version of the one used in the previous national RSA of Iran performed by the research center [10]. The revision was done through a series of expert panel meetings, and new items and questions were added that met the desired objectives. Sixty nine items were classified in 9 different parts including: 1) socioeconomic data (at the time of data collection), 2) family data, 3) first use data, 4) lifetime drug use, 5) current drug of dependency, 6) injection data, 7) high risk behavior, 8) treatment data, and 9) social network.

\section{Independent data}

Data included in this study included the following parts:

I) socio-demographic data: Data consisted age, age of beginning addiction, age of beginning injection, duration of injection, gender, educational level, marital status, living place, status of home, status of employment, alone living, income, legal income, illegal income, drug sell income, monthly family income, cigarette smoking, family history of cigarette smoking, family history of drug use

II) Drug related data consisted monthly money that IDUs used for dominant substance, first place of drug use, first situation of drug use, most reason for first drug use, first pesrson that who suggested drug use, dominant drug that current injectors was used(type of drug), poly drug use and history of drug problems treatment.

III) Injection related data consisted first place of injection, situation of first injection, cause of first injection, frequency of injection in the past years, usual place of injection and alone injection.

IV) Non-sexual high risk behaviors consisted of history of arrest, and history of imprisonment.

To make the final costs internationally comparable, the costs which were registered in Iranian Rials were converted to purchase power parity or international Dollar (PPP\$). The conversion rate for PPP\$ was based on a recently published Iranian study, which had reached at an estimation of PPP\$ equal to 2727 Rials according to the information from the Central Bank of Iran and the World Bank database [11].

\section{Outcome}

Lifetime needle and syringe sharing was defined as borrowing or lending syringe, needle or other injection equipments at least once in their life [12-14]. The most important cause for needle and syringe sharing was also included, with a multiple choice question. Answers included "no access to sterile syringes", "to get more pleasure", "quick injection", "being sure at the shared syring", "financial limitations", "not aware of possible risk", "easy injection" and "peer pressure" [15-17].

\section{Statistical analysis}

The data obtained in the SPSS for Windows 13 statistical package. In order to present quantitative data, median (percentile $25 \%=\mathrm{Q} 1$ and percentile $75 \%=\mathrm{Q} 3$ ), mean 
and standard deviation was used. In order to compare the qualitative variables between those with and without "needle and syringe sharing", chi-square test was used. The comparison of age between two groups was done with t-test and expenditures of drug use between two groups with Mann-Whitney. Multivariate stepwise logistic regression was used to determine the predictors of lifetime syring sharing. P value $<0.05$ was considered significant.

\section{Results}

Mean age at study, age at first drug use, age at first injection, and duration of injection of the participants were $31.3 \pm 8.3,18.6 \pm 5.4,25.9 \pm 6.7$ and $7.4 \pm 6.3$, respectively. Most participants were Muslim, lived in urban area, single, with a lower diploma educational level.

\section{Needle and syringe sharing}

From all 2091 IDUs, 749(35.8\%) reported lifetime experience of needle and syringe sharing. Most frequent causes for needle and syringe sharing included "no access to sterile syringes" ( $n=437 ; 20.9 \%)$, "to get more pleasure" (n $=274 ; 13.1 \%)$, "quick injection" ( $\mathrm{n}=164 ; 7.8 \%)$, "being sure at the shared syring" ( $\mathrm{n}=128 ; 6.1 \%)$, "financial limitations" ( $\mathrm{n}=128 ; 6.1 \%)$, "not aware of possible risk" (n $=99 ; 4.7 \%)$, "easy injection" $(\mathrm{n}=94 ; 4.5 \%)$ and "peer pressure" (n=61;2.9\%).

\section{Associates of Needle and syringe sharing Socio-demographic data}

IDUs with lifetime syring sharing had a higher mean age $(32.3 \pm 8.9$ vs. $31.4 \pm 8.1 ; \mathrm{p}=0.02)$, lower age of first drug use $(17.9 \pm 5$ vs. $18.6 \pm 5.4 ; \mathrm{p}=0.005)$, higher duration of injection $(6.5 \pm 6.3$ vs. $5.4 \pm 5.5 ; \mathrm{p}<0.001)$. Age at first injection was not linked to lifetime syring sharing (25.8 \pm 6.8 vs. $26.1 \pm 6.7 ; p=0.28)$. IDUs with lifetime syring sharing had lower monthly family income (733 ppp\$, Q1 $=330 \mathrm{ppp} \$, \mathrm{Q} 3=1283$ ppp $\$$ vs. 807 ppp $\$, \mathrm{Q} 1=476$ ppp\$, Q3 = 1466 ppp\$; p < 0.001). Overall monthly paiment on drugs were not linked to lifetime syring sharing (586 ppp\$, Q1 = 330 ppp\$, Q3 = 1063 ppp $\$$ vs. 550 ppp\$, Q1 = 366 ppp\$, Q3 = 1100 ppp \$; p = 0.44). Bivariate analysis showed that needle and syringe sharing was significantly higher in females, those who lived in rural area, those who were illiterate, those who were separate/ divorce/widow, homeless, those who lived alone, those jobless, those with illegal income, those with drug related income and those with drug use family members (Table 1).

\section{Substance-related and injection-related data}

Needle and syringe sharing was higher in IDUs who used heroin $(331,41.3 \%$ vs. 418,32.4\%; p < 0.001), was lower in those who used opioium $(47,23.6 \%$ vs.702,37.1\%; p < $0.001)$ and was lower in those who used Amphetamines $(12,15.6 \%$ vs. $737,36.6 \%$; $p<0.001)$. Poly drug users was associated with needle and syringe sharing (321, 40.5\% vs. $415,33.3 \%$; $\mathrm{p}=0.001$ ). (Table 2).

Needle and syringe sharing was lower in those who alone inject (most of times) and home as first place of injection (Table 3).

\section{High risk behaviors}

Lifetime needle and syringe sharing was significantly higher in those IDU who reported extramarital sexual relation) $480,64.1 \%$ vs. $269,35.9 \%$; p < 0.001), history of being arrested by police in the past year(507,67.7\% vs. $242,32.3 \%$; $\mathrm{p}<0.001)$ and history of imprisonment in the past year( $455,60.7 \%$ vs. $294,39.3 \%$; p < 0.001).

\section{Logistic regression}

Multivariate logistic regression showed that the likelihood of lifetime needle and syringe sharing was increased by female gender $(\mathrm{OR}=2.68,95 \% \mathrm{CI}=1.25-5.72, \mathrm{p}=0.01)$, being jobless $(\mathrm{OR}=1.87,95 \% \mathrm{CI}=1.41,2.47, \mathrm{p}=0.001)$, having illegal income $(\mathrm{OR}=1.61,95 \% \mathrm{CI}=1.21-2.15, \mathrm{p}$ $<0.001)$, drug use by family members (OR $=1.47,95 \% \mathrm{CI}$ $=1.12-1.92, \mathrm{p}=0.005)$, first drug use in roofless public place (Odds Ratio $=1.55,95 \% \mathrm{CI}=1.15-2.09, \mathrm{p}=0.003$ ), first drug use in roofed public place (Odds Ratio $=1.62$, $95 \% \mathrm{CI}=1.08-2.42, \mathrm{p}=0.01)$, pleasure/enjoyment as causes of first injection $(\mathrm{OR}=1.58,95 \% \mathrm{CI}=1.2-2.07, \mathrm{p}$ $=0.001)$, usual injection at groin $(\mathrm{OR}=1.64,95 \% \mathrm{CI}=$ $1.11-2.42, \mathrm{p}=0.01)$, usual injection at scrotum $(\mathrm{OR}=$ $1.57,95 \% \mathrm{CI}=1.06-2.31, \mathrm{p}=0.02)$, lifetime experience of nonfatal overdose $(\mathrm{OR}=1.68,95 \% \mathrm{CI}=1.28-2.21, \mathrm{p}<$ $0.001)$, and history of arrest in past year $(\mathrm{OR}=1.38$, $95 \% \mathrm{CI}=1.04-1.82, \mathrm{p}=0.02)$ and was decreased by being alone at most injections $(\mathrm{OR}=0.51,95 \% \mathrm{CI}=0.38-0.68$, $\mathrm{p}<0.001$ ). (Table 4).

\section{Discussion}

In Iran, 1 of 3 IDUs report the history of lifetime needle and syringe sharing. The likelihood of lifetime needle and syringe sharing was increased by female gender, being jobless, having illegal income, drug use by family members, pleasure/enjoyment as causes of first injection, first injection in roofless and roofed public places, usual injection at groin, usual injection at scrotum, lifetime experience of nonfatal overdose, and history of arrest in past year and was decreased by being alone at most injections.

Regarding the literature on syring sharing, according to a study in Mexico, 2005, 80\% of the IDUs reported that they share syringes regularly with other IDUs [18]. In another study in Canada $27.6 \%$ of the participants reported sharing needles during the past 6 months [12].

Our study showed that needle and syringe sharing was increased in female IDUs. In line with our finding, one 
Table I: The comparison of syringe sharing between socio-demographic variables

\begin{tabular}{|c|c|c|c|c|}
\hline & & \multicolumn{2}{|c|}{ Syringe sharing } & \multirow[b]{2}{*}{$P$ value } \\
\hline & & Count & Percent & \\
\hline \multirow[t]{2}{*}{ Sex } & Male & 713 & $35.4 \%$ & 0.029 \\
\hline & Female & 35 & $47.9 \%$ & \\
\hline \multirow[t]{2}{*}{ Religious type } & Muslim & 737 & $36.0 \%$ & 0.164 \\
\hline & other & 2 & $16.7 \%$ & \\
\hline \multirow[t]{2}{*}{ Living place } & Urban & 640 & $35.0 \%$ & 0.004 \\
\hline & Rural & 62 & $47.7 \%$ & \\
\hline \multirow[t]{3}{*}{ Education level } & Illiterate or were barely able to read and write & 94 & $43.7 \%$ & 0.002 \\
\hline & Under diploma & 607 & $36.0 \%$ & \\
\hline & Upper diploma & 35 & $25.0 \%$ & \\
\hline \multirow[t]{3}{*}{ Marital status } & single & 421 & $38.0 \%$ & $<0.001$ \\
\hline & Married & 166 & $26.4 \%$ & \\
\hline & Separate, divorce and widow & 153 & $46.8 \%$ & \\
\hline \multirow[t]{2}{*}{ Status of home } & Having home & 575 & $32.4 \%$ & 0.000 \\
\hline & Homeless & 144 & 62.1 & \\
\hline \multirow[t]{2}{*}{ Alone Living } & No & 567 & $32.8 \%$ & $<0.001$ \\
\hline & Yes & 182 & $50.6 \%$ & \\
\hline \multirow[t]{2}{*}{ Occupation } & No & 353 & $28.5 \%$ & $<0.001$ \\
\hline & Yes & 396 & $46.5 \%$ & \\
\hline \multirow[t]{3}{*}{ Boss type } & State & 13 & $25.0 \%$ & 0.591 \\
\hline & Private & 114 & $30.9 \%$ & \\
\hline & khisfarrma & 126 & $28.5 \%$ & \\
\hline \multirow[t]{2}{*}{ Drug Income } & No & 462 & $30.2 \%$ & $<0.001$ \\
\hline & Yes & 267 & $52.0 \%$ & \\
\hline \multirow[t]{2}{*}{ Job Income } & No & 409 & $43.1 \%$ & $<0.001$ \\
\hline & Yes & 320 & $29.3 \%$ & \\
\hline \multirow[t]{2}{*}{ Illegal Income } & No & 412 & $28.5 \%$ & $<0.001$ \\
\hline & Yes & 317 & $53.0 \%$ & \\
\hline
\end{tabular}


Table I: The comparison of syringe sharing between socio-demographic variables (Continued)

\begin{tabular}{|c|c|c|c|c|}
\hline \multirow[t]{2}{*}{ Legal Non Job Income } & No & 345 & $35.3 \%$ & \multirow[t]{2}{*}{0.775} \\
\hline & Yes & 384 & $36.0 \%$ & \\
\hline \multirow[t]{2}{*}{ Furniture sell Income } & No & 683 & $35.5 \%$ & 0.483 \\
\hline & Yes & 46 & $38.7 \%$ & \\
\hline \multirow[t]{3}{*}{ Lifetime smoking } & Never smoking & 23 & $34.3 \%$ & 0.636 \\
\hline & Current smoking & 690 & $36.1 \%$ & \\
\hline & Past smoking & 36 & $31.9 \%$ & \\
\hline \multirow[t]{2}{*}{ cigarette smoking by parents } & No & 296 & $29.8 \%$ & $<0.001$ \\
\hline & Yes & 453 & $41.3 \%$ & \\
\hline \multirow[t]{2}{*}{ cigarette smoking by other members of family } & No & 178 & $26.8 \%$ & $<0.001$ \\
\hline & Yes & 571 & $40.0 \%$ & \\
\hline \multirow[t]{2}{*}{ Substance use by parents } & No & 475 & $31.3 \%$ & $<0.001$ \\
\hline & Yes & 274 & $47.7 \%$ & \\
\hline \multirow[t]{2}{*}{ Substance use by members of family } & No & 337 & $29.0 \%$ & $<0.001$ \\
\hline & Yes & 412 & $44.3 \%$ & \\
\hline
\end{tabular}

study of gender effect on needle and syringe sharing bahavior of IDUs showed that females were more likely to share injecting equipment [19-21]. A recently qualitative study of Iranian female IDUs reported sharing syringes as a typical behavior [8]. Different risk profile of HIV among male and female IDUs is in line with these reports [22]. So, gender should be addressed as an important variable in needle exchange programs [23].

In our study, jobless IDUs and those who had illegal income had higher rate of needle and syringe sharing. Review of literature shows a link between unemployment of IDUs and needle and syringe sharing behavior [24,25]. Similarly, syringe has been reported to be linked to not having a legal income [26] or engaging in illegal jobs [27]. These may be due to the financial strains to buy stril syrings, and free syrings should be given to these IDUs.

In our study, drug injectors with drug user family members were at higherrisk for needle and syringe sharing. Needle and syringe sharing is reported to be higher in IDUs with a familial network for drug use [28]. Oe study reported that the role of family network on the needlesharing behavior is more severe in women in comparison with men [29].
In our study, first drug use at public places was linked to more syringe sharering. According to the literature, IDUs who usually inject in public places have oppurtunity for needle and syringe sharing [30,31]. A qualitative study in Iran also confirms this association [8].

Alone injection in compare to injection with someone else, is linked to the lack of oppurtiunity of needle and syringe sharing. In one study in US, markedly lower rates of needle and syringe sharing was observed in IDUs who injecting alone [32]. Injection in the context of social and familial networks is known to be associated with higher needle and syringe sharing [28]. Those who try to keep their injecting hidden, may benefit of a reduced risk of syring sharing [32].

We found that injection in groin and linked to higher needle and syringe sharing in IDUs. However we did not find any study in this regard, studies of bodily injection sites of IDUs have reported a clear progression in sites used, from the upper extrimities, at initial injection to the use of sites such as the groin and scrotum the years after $[33,34]$. Unjection in sites such as the groin and scrotum were linked to a greater number of injection-related problems. 
Table 2: The comparison of syringe sharing between drug use-related variables

\begin{tabular}{|c|c|c|c|c|c|}
\hline & & & \multicolumn{2}{|c|}{ Syringe sharing } & \multirow[t]{2}{*}{$P$ value } \\
\hline & & & Count & Percent & \\
\hline \multirow[t]{10}{*}{ Dominant drug usage } & Opioium & Yes & 47 & $23.6 \%$ & $<0.001$ \\
\hline & & No & 702 & $37.1 \%$ & \\
\hline & Amphetamines & Yes & 12 & $15.6 \%$ & $<0.001$ \\
\hline & & No & 737 & $36.6 \%$ & \\
\hline & Heroin & Yes & 331 & $41.3 \%$ & $<0.001$ \\
\hline & & No & 418 & $32.4 \%$ & \\
\hline & Purified Heroin & Yes & 202 & $35.9 \%$ & 0.943 \\
\hline & & No & 547 & $35.8 \%$ & \\
\hline & Norjesic & Yes & 109 & $35.6 \%$ & 0.937 \\
\hline & & No & 640 & $35.9 \%$ & \\
\hline \multirow[t]{3}{*}{ First place of drug use } & Own home, home of friends, student home & & 338 & $32.1 \%$ & 0.003 \\
\hline & Roofless public places & & 225 & $40.7 \%$ & \\
\hline & Roofed public places & & 95 & $36.3 \%$ & \\
\hline \multirow[t]{2}{*}{ First situation of drug use } & $\begin{array}{l}\text { Specific situations } \\
\text { (family party, friends party, mourning ceremony, gatherings } \\
\text { with friends) }\end{array}$ & & 559 & $35.5 \%$ & 0.524 \\
\hline & Without Specific situation & & 187 & $37.1 \%$ & \\
\hline \multirow{2}{*}{$\begin{array}{l}\text { What was the most important event that } \\
\text { leaded you to first use? }\end{array}$} & Specific events(work related, familial/domestic, educational) & & 360 & $38.6 \%$ & 0.029 \\
\hline & Without Specific event & & 376 & $34 \%$ & \\
\hline \multirow[t]{2}{*}{ Most important reason for beginning drug use } & Pleasure/enjoyment, recreation, Konjkavi & & 402 & $34 \%$ & 0.033 \\
\hline & Without pleasure/enjoyment & & 343 & $38.6 \%$ & \\
\hline \multirow{5}{*}{$\begin{array}{l}\text { First person who suggested you to use } \\
\text { substance }\end{array}$} & Family or relatives & & 149 & $42.2 \%$ & 0.015 \\
\hline & Friends & & 377 & $35.5 \%$ & \\
\hline & Assistants & & 45 & $31.5 \%$ & \\
\hline & Others & & 52 & $29.5 \%$ & \\
\hline & Without mover & & 96 & $32.0 \%$ & \\
\hline
\end{tabular}


Table 3: The comparison of syringe sharing between injection-related variables

\begin{tabular}{|c|c|c|c|c|c|}
\hline & & & \multicolumn{2}{|c|}{ Syringe sharinge } & \multirow[b]{2}{*}{ P value } \\
\hline & & & Number & Percent & \\
\hline \multirow[t]{3}{*}{ First place of injection } & Own home, home of friends, student home & & 382 & $31.6 \%$ & 0.003 \\
\hline & Roofless public places & & 206 & $41.4 \%$ & \\
\hline & Roofed public places & & 88 & $50 \%$ & \\
\hline \multirow[t]{2}{*}{ Frequency of injection } & Lower than once per day & & 145 & $31 \%$ & 0.001 \\
\hline & Once and higher per day & & 573 & $38.2 \%$ & \\
\hline \multirow[t]{12}{*}{ Site of injection } & Hand & No & 76 & $34.4 \%$ & 0.639 \\
\hline & & Yes & 673 & $36.0 \%$ & \\
\hline & Foot & No & 393 & $29.9 \%$ & $<0.001$ \\
\hline & & Yes & 356 & $45.8 \%$ & \\
\hline & Groin & No & 393 & $29.9 \%$ & $<0.001$ \\
\hline & & Yes & 160 & $58.4 \%$ & \\
\hline & Testis & No & 575 & $32.1 \%$ & $<0.001$ \\
\hline & & Yes & 174 & $57.6 \%$ & \\
\hline & Neck & No & 622 & $33.4 \%$ & $<0.001$ \\
\hline & & Yes & 127 & $56.2 \%$ & \\
\hline & Other & No & 725 & $35.6 \%$ & 0.316 \\
\hline & & Yes & 24 & $42.1 \%$ & \\
\hline \multirow[t]{12}{*}{ Cause of first injection } & Speed of effect & No & 446 & $32.9 \%$ & $<0.001$ \\
\hline & & Yes & 303 & $41.2 \%$ & \\
\hline & pleasure/enjoyment & No & 404 & $30.7 \%$ & $<0.001$ \\
\hline & & Yes & 345 & $44.5 \%$ & \\
\hline & Effect less of before mode of drug use & No & 526 & $33.3 \%$ & $<0.001$ \\
\hline & & Yes & 223 & $43.6 \%$ & \\
\hline & Pry & No & 589 & $35.9 \%$ & 0.864 \\
\hline & & Yes & 160 & $35.5 \%$ & \\
\hline & Relief of use & No & 573 & $35.2 \%$ & 0.265 \\
\hline & & Yes & 176 & $38.0 \%$ & \\
\hline & Pressure of friends & No & 610 & $35.2 \%$ & 0.208 \\
\hline & & Yes & 139 & $38.7 \%$ & \\
\hline
\end{tabular}


Table 3: The comparison of syringe sharing between injection-related variables (Continued)

\begin{tabular}{|c|c|c|c|c|c|}
\hline & Substance was not out of reach & No & 668 & $35.0 \%$ & 0.007 \\
\hline & & Yes & 81 & $45.0 \%$ & \\
\hline & Low quality of present drugs & No & 665 & $34.5 \%$ & $<0.001$ \\
\hline & & Yes & 84 & $52.2 \%$ & \\
\hline & Lower cost of injection & No & 603 & $32.7 \%$ & $<0.001$ \\
\hline & & Yes & 146 & $59.6 \%$ & \\
\hline & Treatment of addiction & No & 736 & $36.2 \%$ & 0.031 \\
\hline & & Yes & 13 & $22.4 \%$ & \\
\hline Where do you usually inject? & Own's home & No & 375 & $39.8 \%$ & 0.001 \\
\hline & & Yes & 374 & $32.6 \%$ & \\
\hline & Park & No & 575 & $33.3 \%$ & $<0.001$ \\
\hline & & Yes & 174 & $48.1 \%$ & \\
\hline & School & No & 743 & $35.8 \%$ & 0.436 \\
\hline & & Yes & 6 & $46.2 \%$ & \\
\hline & Street and lane & No & 554 & $32.2 \%$ & $<0.001$ \\
\hline & & Yes & 195 & $52.2 \%$ & \\
\hline & "Kharabe" & No & 385 & $26.2 \%$ & $<0.001$ \\
\hline & & Yes & 364 & $58.4 \%$ & \\
\hline & Student's house & No & 740 & $35.7 \%$ & 0.208 \\
\hline & & Yes & 9 & $50 \%$ & \\
\hline & Soldiers' camp & No & 737 & $35.5 \%$ & $<0.001$ \\
\hline & & Yes & 12 & $80 \%$ & \\
\hline & Prison & No & 663 & $33.5 \%$ & $<0.001$ \\
\hline & & Yes & 86 & $76.8 \%$ & \\
\hline & Work place & No & 661 & $35.5 \%$ & 0.44 \\
\hline & & Yes & 88 & $38.1 \%$ & \\
\hline & Friend's home & No & 473 & $34.6 \%$ & 0.096 \\
\hline & & Yes & 276 & $38.2 \%$ & \\
\hline With whom do you usually inject? & Alone & & 493 & $33.0 \%$ & $<0.001$ \\
\hline & With others(friends, relatives) & & 256 & $43.0 \%$ & \\
\hline
\end{tabular}


Table 4: Logestic regression for having syringe sharing between socio-demographic, drug use and injection-related variables in intravenous drug users (IDUs)

\begin{tabular}{|c|c|c|c|c|}
\hline & \multirow[b]{2}{*}{$P$ value } & \multirow[b]{2}{*}{ OR } & \multicolumn{2}{|c|}{ 95\% Confidence Interval for odds } \\
\hline & & & Lower & Upper \\
\hline Gender(female) & & & 1.259 & 5.725 \\
\hline Jobless & $<.001$ & 1.870 & 1.412 & 2.478 \\
\hline Illegal Income & .001 & 1.617 & 1.217 & 2.150 \\
\hline Substance use of family members & .005 & 1.471 & 1.125 & 1.925 \\
\hline pleasure/enjoyment as cause of first injection & .001 & 1.583 & 1.209 & 2.074 \\
\hline First place of drug use (Roofless public places) & .003 & 1.558 & 1.157 & 2.097 \\
\hline First place of drug use (Roofed public places) & .019 & 1.621 & 1.084 & 2.424 \\
\hline Alone injection & $<.001$ & .515 & .388 & .682 \\
\hline Groin injection & .013 & 1.642 & 1.111 & 2.427 \\
\hline Testis injection & .022 & 1.573 & 1.068 & 2.318 \\
\hline Nonfatal overdose & $<.001$ & 1.686 & 1.282 & 2.216 \\
\hline Arresting in past year & .022 & 1.385 & 1.049 & 1.829 \\
\hline
\end{tabular}

One study showed a link between more severe drug injecting and share needles [25].

We found a link between needle and syringe sharing and nonfatal overdose, which are both high risk behaviors. One study in USA showed that overdosing may be associated with borrowing syringes [35] but in another study in England in 1994 to 1995 self-reported overdose was not linked to syring sharing [36]. We also found arrest in the past year as a associated factor with needle and syringe sharing. Similar results have been reported by two studies in Pakistan and Australia [37,38]. Other Risk Behavior Surveys have shown a Co-occurrence of health-risk behaviors among differerent populations $[39,40]$. These studies have explained their findings with the gateway theory.

In Iran, evidences show that access to a needle and syringe program (NSP) will reduce the needle and needle and syringe sharing practices. The authors suggested NSPs to be intensified in settings with concentrated HIV epidemics among IDUs in Iran [13].

There are some limitations to this study. First, this study is one of a series of secondary analyses [41] and we did not have data on detail of needle and syringe sharing behav- iors. Second, the results rely on participants' self-report data, because self-reports are affected by response bias. Respondents may tend to deny or underreport their syring sharing due to social disirability [41]. Third, because of the cross-sectional design of this study, it is not possible to draw a conclusion on the direction of the associations. Endly, in this study we asked lifetime syring sharing, and we did not limit it by asking sharing during past year or last injection.

\section{Conclusion}

In designing interventions for HIV prevention in Iran, through decrease of needle and syringe sharing among IDUs, the introduced variables must be considered. Further studies in this regard are needed.

\section{Competing interests}

The authors declare that they have no competing interests.

\section{Authors' contributions}

SA performed the secondary analysis. MJ and MR prepared the draft of the manuscript. HN, HR helped SA in interpretation of the secondary analysis. All authors read and approved the final manuscript. HR, HN, RN, MS and PS participated in the design of the original survey. 


\section{Acknowledgements}

We are thankful for all our collaborators who participated in the acquisition of data. We acknowledge Mohammad Mahdi Naghizadeh who supervised the data analysis.

\section{References}

I. MAP Network: AIDS in Asia: Face the Facts. A Comprehensive Analysis of the AIDS Epidemic in Asia. Washington, DC: Monitoring the AIDS Pandemic (MAP) Network; 2004

2. Iranian Ministry of Health and Medical Education: Statistics on HIVI AIDS in Iran 2003. . (Published in Persian)

3. Rahbar RA, Rooholamini S, Khoshnood K: Prevalence of HIV infection and other bloodborne infections in incarcerated and non-incarcerated Injection Drug Users (IDUs) in Mashhad, Iran. Int J Drug Policy 2004, I 5(2): I5I-I 55.

4. Razzaghi EM, Rahimi Movaghar A, Hosseini M, Madani S, Chatterjee A: Rapid Situation Assessment of Drug Abuse in Iran Iranian Welfare Organization and UNDCP. 1999.

5. Day C, Nassirimanesh B, Shakeshaft A, Dolan K: Patterns of drug use among a sample of drug users and injecting drug users attending a General Practice in Iran. Harm Reduct J 2006, 3:2.

6. Bailey SL, Ouellet LJ, Mackesy-Amiti ME, Golub ET, Hagan H, Hudson SM, Latka MH, Gao W, Garfein RS, DUIT Study Team: Perceived risk, peer influences, and injection partner type predict receptive syringe sharing among young adult injection drug users in five U.S. cities. Drug Alcohol Depend 2007, 91 (Suppl I):SI8-29.

7. Razani N, Mohraz M, Kheirandish $P$, Malekinejad M, Malekafzali $H$, Mokri A, McFarland W, Rutherford G: HIV risk behavior among injection drug users in Tehran, Iran. Addiction 2007, I 02(9): | 472-82.

8. Razzaghi EM, Movaghar AR, Green TC, Khoshnood K: Profiles of risk: a qualitative study of injecting drug users in Tehran, Iran. Harm Reduct J 2006, I8(3): I2.

9. Vazirian M, Nassirimanesh B, Zamani S, Ono-Kihara M, Kihara M, Ravari SM, Gouya MM: Needle and syringe sharing practices of injecting drug users participating in an outreach HIV prevention program in Tehran, Iran: a cross-sectional study. Harm Reduct J 2005, 7;2:19.

10. Razzaghi E, Rahimi A, Hosseni M, Madani S: Rapid Situation Assessment (RSA) of Drug Abuse in Iran. Prevention Department, State Welfare Organization, Ministry of Health, IR of Iran and United Nations International Drug Control Program 1999.

II. Ghoddousi K, Ramezani MK, Assari S, Lankarani MM, Amini M, Khedmat $\mathrm{H}$, Hollisaaz MT: Primary kidney disease and post-renal transplantation hospitalization costs. Transplant Proc 2007, 39(4):962-5.

12. Wood E, Tyndall MW, Spittal PM, Li K, Kerr T, Hogg RS, Montaner JS, O'Shaughnessy MV, Schechter MT: Unsafe injection practices in a cohort of injection drug users in Vancouver: could safer injecting rooms help? MAJ 200I, 21 ; I 65(4):405- 10.

13. Zamani S, Vazirian M, Nassirimanesh B, Razzaghi EM, Ono-Kihara M, Mortazavi Ravari S, Gouya MM, Kihara M: Needle and Syringe Sharing Practices Among Injecting Drug Users in Tehran: A Comparison of Two Neighborhoods, One with and One Without a Needle and Syringe Program. AIDS Behav 2008 in press.

14. Robertson MJ, Clark RA, Charlebois ED, Tulsky J, Long HL, Bangsberg DR, Moss AR: HIV seroprevalence among homeless and marginally housed adults in San Francisco. Am J Public Health 2004, 94(7): I207-I7.

15. Rácz J, Gyarmathy VA, Neaigus A, Ujhelyi E: Injecting equipment sharing and perception of HIV and hepatitis risk among injecting drug users in Budapest. AIDS Care 2007, I 9(I):59-66.

16. Thanh DC, Moland KM, Fylkesnes K: The context of HIV risk behaviours among HIV-positive injection drug users in Viet Nam: moving toward effective harm reduction. BMC Public Health 2009, 6;9:98.

17. Sarang A, Rhodes T, Platt L, Kirzhanova V, Shelkovnikova O, Volnov $\checkmark$, Blagovo D, Rylkov A: Drug injecting and syringe use in the HIV risk environment of Russian penitentiary institutions: Qualitative study. Addiction 2006, 10 I ( I 2): 1787-96.

18. Strathdee SA, Fraga WD, Case P, Firestone M, Brouwer KC, Perez SG, Magis C, Fraga MA: "Vivo para consumirla y la consumo para vivir" ["I live to inject and inject to live"]: high-risk injection behaviors in Tijuana, Mexico. J Urban Health 2005, 82(3 Suppl 4):iv58-73

19. Evans JL, Hahn JA, Page-Shafer K, Lum PJ, Stein ES, Davidson PJ, Moss AR: Gender differences in sexual and injection risk behavior among active young injection drug users in San Francisco (the UFO Study). J Urban Health 2003, 80( I): I37-46.

20. Montgomery SB, Hyde J, De Rosa CJ, Rohrbach LA, Ennett S, Harvey SM, Clatts M, Iverson E, Kipke MD: Gender differences in HIV risk behaviors among young injectors and their social network members. Am J Drug Alcohol Abuse 2002, 28(3):453-75.

21. Lum PJ, Sears C, Guydish J: Injection risk behavior among women syringe exchangers in San Francisco. Subst Use Misuse 2005, 40(I I): 168I-96

22. Frajzyngier V, Neaigus A, Gyarmathy VA, Miller M, Friedman SR: Gender differences in injection risk behaviors at the first injection episode. Drug Alcohol Depend 2007, I 0;89(2-3): |45-52.

23. Azim T, Chowdhury El, Reza M, Ahmed M, Uddin MT, Khan R, Ahmed G, Rahman M, Khandakar I, Khan SI, Sack DA, Strathdee SA: Vulnerability to HIV infection among sex worker and nonsex worker female injecting drug users in Dhaka, Bangladesh: evidence from the baseline survey of a cohort study. Harm Reduct J 2006, 3:33.

24. Bluthenthal RN, Do DP, Finch B, Martinez A, Edlin BR, Kral AH: Community characteristics associated with HIV risk among injection drug users in the San Francisco Bay Area: a multilevel analysis. J Urban Health 2007, 84(5):653-66.

25. Magis-Rodríguez C, Brouwer KC, Morales S, Gayet C, Lozada R, Ortiz-Mondragón R, Ricketts EP, Strathdee SA: HIV prevalence and correlates of receptive needle sharing among injection drug users in the Mexican-U.s. border city of Tijuana. J Psychoactive Drugs 2005, 37(3):333-9.

26. Rodés A, Vall M, Casabona J, Nuez M, Rabella N, Mitrani L: Prevalence of human immunodeficiency virus infection and behaviors associated with its transmission among parenteral drug users selected on the street. Med Clin (Barc) 1998, I I | ( I 0):372-7.

27. Perngmark $P$, Celenta DD, Kawichai $S$ : Needle sharing among southern Thai drug injectors. Addiction 2003, 98(8): I I53- I I6I.

28. Shaw SY, Shah L, Jolly AM, Wylie JL: Determinants of injection drug user (IDU) syringe sharing: the relationship between availability of syringes and risk network member characteristics in Winnipeg, Canada. Addiction 2007, I 02(1 0): 1626-35.

29. Brook DW, Brook JS, Whiteman M, Win PT, Gordon-Maloul C, Roberto J, Amundsen F, Masci JR, Catalogne JD: Psychosocial risk factors for HIV transmission in female drug abusers. Am J Addict 6(2): I24-34.

30. Neaigus A, Friedman SR, Curtis R, Des Jarlais DC, Furst RT, Jose B, Mota $P$, Stepherson $B$, Sufian $M$, Ward $T$ : The relevance of drug injectors' social and risk networks for understanding and preventing HIV infection. Soc Sci Med 1994, 38(I):67-78.

31. Hunt N, Lloyd C, Kimber J, Tompkins C: Public injecting and willingness to use a drug consumption room among needle exchange programme attendees in the UK. Int J Drug Policy 2007, I 8(I):62-5.

32. Hagan H, Campbell JV, Thiede H, Strathdee SA, Ouellet L, Latka M, Hudson S, Garfein RS, DUIT Study Team: Injecting alone among young adult IDUs in five US cities: evidence of low rates of injection risk behavior. Drug Alcohol Depend 2007, 9 I(Suppl I):S48-55

33. Somers WJ, Lowe FC: Localized gangrene of the scrotum and penis: a complication of heroin injection into the femoral vessels. J Urol I 986, I36(I): I I |-3.

34. Darke S, Ross J, Kaye SL: Physical Injecting Sites Among Injecting Drug Users in Sydney, Australia. Drug and Alcohol Dependence 200I, 62:77-82.

35. Ochoa KC, Hahn JA, Seal KH, Moss AR: Overdosing among young injection drug users in San Francisco. Addict Behav 200I, 26(3):453-60

36. Powis B, Strang J, Griffiths P, Taylor C, Williamson S, Fountain J, Gossop $M$ : Self-reported overdose among injecting drug users in London: extent and nature of the problem. Addiction 1999, 94(4):47I-8.

37. Strathdee SA, Zafar T, Brahmbhatt H, Baksh A, UI Hassan S: Rise in needle sharing among injection drug users in Pakistan during the Afghanistan war. Drug Alcohol Depend 2003, 20;7 I(I): I7-24. 
38. Lawrinson P, Copeland J, Indig D: Regional differences in injecting practices and other substance use-related behaviour among entrants into opioid maintenance pharmacotherapy treatment in New South Wales, Australia. Drug Alcohol Depend 2006, 82(SuppI I):S95-I02.

39. Baskin-Sommers A, Sommers I: The co-occurrence of substance use and high-risk behaviors. J Adolesc Health 2006, 38(5):609-I I.

40. Kandel DB, Yamaguchi K, Chen K: Stages of Progression in Drug Involvement from Adolescence to Adulthood: Further Evidence for the Gateway Theory. J Stud Alcohol 1992, 53:447-457.

4I. Narenjiha H, Rafiey H, Jahani MR, Assari S, Moharamzad Y, Roshanpazooh M: Substance-dependent professional drivers in Iran: a descriptive study. Traffic Inj Prev 2009, 10(3):227-30.

42. Gibson DR, Hudes ES, Donovan D: Estimating and Correcting for Response Bias in Self-Reported HIV Risk Behavior. J Sex Research 1999, 36(I):96-101.

Publish with Bio Med Central and every scientist can read your work free of charge

"BioMed Central will be the most significant development for disseminating the results of biomedical research in our lifetime. "

Sir Paul Nurse, Cancer Research UK

Your research papers will be:

- available free of charge to the entire biomedical community

- peer reviewed and published immediately upon acceptance

- cited in PubMed and archived on PubMed Central

- yours - you keep the copyright

Submit your manuscript here:

http://www.biomedcentral.com/info/publishing_adv.asp
BiolMedcentral 